\title{
Environmental impacts of mining and processing of sand-gravel mix
}

\author{
Lezhinka Sozaeva ${ }^{1 *}$, Arthur Kagermazov ${ }^{1}$ \\ ${ }^{1}$ High-Mountain Geophysical Institute, Nalchik, 360030, Russia
}

\begin{abstract}
The work is devoted to the assessment of the negative impact of pollutant emissions on the air in the extraction and processing of sand and gravel. The maximum one-time and total emissions created by unorganized sources of one of the actually functioning enterprises are determined. The results of the calculation of the dispersion of the main pollutant (inorganic dust) are given. It is shown that the emissions of inorganic dust on the area of the enterprise exceed the values of the maximum permissible concentration and become lower than the MPC only outside the sanitary protection zone This demonstrates the need to comply with and control hygienic standards of ambient air quality near such enterprises.
\end{abstract}

\section{Introduction}

Mineral raw material resources are a basis of economic body height and independence of any state. In the steady economic situation providing normal activity of all industries of the country, consumption of nonmetallic structural materials, as a rule, grows.

The most important for the construction are such non-metallic construction materials as crushed stone, sand, gravel, limestone, gypsum, anhydrite, etc. Their production is more than one and a half times the production of the ore and energy raw materials taken together. The overwhelming amount of non-metallic materials used is mined by the open method.

The open method of mining has the most negative impact on the environmental situation in the area of mining. As a result of anthropogenic environmental impact in the area of the quarries, there is a noticeable deterioration of the ecological conditions of human existence.

It has been established that the main types of impact of opencast mining of common minerals are the direct destruction of natural ecosystems in local areas within the mining allotment. Outside the mining allotment, the main impact is due to dusting and emissions of pollutants from industrial explosives explosions, engines of road-building equipment and vehicles within the boundaries of sanitary protection zones of developments.

\footnotetext{
*Corresponding author: 1jk_62@ rambler.ru
} 


\section{Materials and research methods}

The purpose of this work is to assess the negative impact of pollutants emitted by enterprises for the production of building materials on the environment. As a research object, Dorgranit, located on the territory of the Chegem district of the Kabardino-Balkarian Republic, is considered. The company specializes in the extraction and processing of gravel-sand mixture (gravel) for the production of building materials (screenings, crushed stone).

To achieve this goal, it is necessary to identify the sources of pollutant emissions into the atmosphere, estimate the emissions of the main pollutants, calculate the dispersion in the area where the enterprise is located and analyze the results. Works devoted to similar problems for enterprises in this region were set forth in publications (Sozaeva L. T., 2018; Sozaeva L.T., Shungarov I. Kh., 2019).

The technological process of production of materials is carried out as follows. The sandgravel mix is mined in an open-pit way by an excavator in a quarry and is delivered by dump trucks for processing to the receiving bins of the crushing and screening lines (CSL). From the receiving bunker gravel to a jaw crusher for its preliminary crushing up to $300 \mathrm{~mm}$. Cone crushers are used for secondary crushing to the desired size. Next, crushed materials are sorted by size on screens: white screenings $(0-10 \mathrm{~mm})$, fine crushed stone $(5-20 \mathrm{~mm})$, large crushed stone $(25-60 \mathrm{~mm}$ ). After sorting, finished products are delivered by conveyor conveyors to open warehouses, from where they are shipped to railway wagons and exported to the consumer. Sand-gravel waste is used for land reclamation. All stages of this process are accompanied by the release of dust, which has a negative impact on the nature and human health. The main pollutant entering the atmosphere during the extraction and processing of sand and gravel mixture is inorganic dust, containing, depending on the type of rock, up to $70 \%$ of free silica.

In the operation of an enterprise, the main sources of inorganic dust entering the atmosphere are: material transfer units, transshipment works in a warehouse, storage of materials, an excavator, receiving hoppers, jaw crushers, cone crushers, screeners, conveyor belts, etc.

At the first stage, an inventory of pollutant emissions was carried out, i.e. identifying and recording sources of air pollution and characterizing emissions. According to the report on the inventory of emissions of pollutants into the atmosphere, this company has 21 unorganized sources. Unorganized sources include emissions entering the air in the form of undirected streams of dust as a result of working in the open air or leakage of the process equipment. Sources equipped with dust treatment plants are classified as organized. There are no organized sources at this enterprise, i.e. dust cleaning is not provided.

Calculation of maximum one-time $(\mathrm{g} / \mathrm{sec})$ and total (tons/ year) emissions from crushing and screening plants was made on the basis of specific indicators of dust emission (Technique, 1998). The emission rate from the storage facilities of dusty materials, at the sites of their overfilling, during transportation and loading and unloading works was calculated using the methodological guidebook (Methodological gratuity, 2000).

These methods allow you to calculate emissions of pollutants, taking into account the weight fraction of the dust fraction; the proportion of dust passing into the aerosol; humidity, size and height of the material transfer, also local meteorological conditions (wind speed). When carrying out calculations, recommendations on the use of the gravitational deposition coefficient were taken into account (Methodological gratuity, 2012).

At the second stage, calculations of the dispersion of pollutant emissions in the surface layer of the atmosphere were carried out. For this, the "Ecologist-4" program was used, in 
which the methods (Order of the Ministry of natural resources and ecology, 2017), approved in the prescribed manner, were implemented. The degree of negative impact of emissions of inorganic dust on atmospheric air is assessed according to the following criterion (Methodological gratuity, 2012):

$$
\frac{C_{i}}{M P C} \leq 1
$$

where $C_{i}$ - is the sum of the maximum surface one-time concentrations of inorganic dust created by the emission of the totality of the sources of a given enterprise at the border of the sanitary protection zone (SPZ); MPC - maximum permissible concentration of inorganic dust in the atmospheric air of populated areas. For this enterprise, the size of the sanitary protection zone is assumed to be $500 \mathrm{~m}$ (SanPiN, 2007). The residential area is located at a distance of $700 \mathrm{~m}$ from the enterprise and outside its sanitary protection zone.

For carrying out the dispersion calculations, the dimensions of the calculated site of the zone of influence of emissions of the enterprise (5400 $\mathrm{m}$ in width and length) and the grid step $(100 \mathrm{~m})$ were specified. Six calculation points were selected, located on the border of the sanitary protection zone. The maximum surface concentrations of inorganic dust were determined at each calculated point and grid nodes by a search of wind speeds and directions. Wind speeds were moving from 0.5 to $5 \mathrm{~m} / \mathrm{sec}$ (wind speed, the repeatability of which, according to long-term data, is $5 \%$ higher than this). Wind direction varied over the entire range from 0 to 360 degrees with an interval of 1 degree. The height of emission sources is equal to the weighted average height of the totality of emission sources combined into one source.

Meteorological characteristics determining the dispersion conditions of pollutants in the atmosphere in the area of the enterprise location were taken (https://www.meteoblue.com):

- $+28^{\circ} \mathrm{C}$ - average maximum outdoor temperature of the hottest month;

$-\quad-3^{\circ} \mathrm{C}$ - average temperature of the coldest month;

- $5 \mathrm{~m} / \mathrm{sec}$ - wind speed, the repeatability of which is exceeded by long-term data is $5 \%$.

\section{The results of the assessment of the negative effects of inorganic dust emitted during the extraction and processing of gravel}

This enterprise extracts and processes 390 thousand tons of sand-gravel mixture per year. The capacity of the technological line is $45 \mathrm{M}^{3} /$ hour (first and second) and $70 \mathrm{M}^{3} /$ hour (third). Under such working conditions, about 19 tons of inorganic dust per year are emitted into the atmospheric air. This pollutant according to the degree of air pollution belongs to the 3rd class of danger; its maximum permissible concentration is $0.3 \mathrm{mg} / \mathrm{m}^{3}$ (Hygienic standards 2.1.6.1338-03, 2003).

In Table 1 presented the characteristics of emissions from sources of negative effects on the atmosphere. 
Table 1. Inorganic dust emission characteristics

\begin{tabular}{|c|c|c|c|}
\hline \multirow[t]{2}{*}{ Technological sites } & \multirow{2}{*}{$\begin{array}{l}\text { The name of the } \\
\text { emission sources }\end{array}$} & \multicolumn{2}{|c|}{ Emissions of the inorganic dust } \\
\hline & & $\begin{array}{c}\text { maximum one- } \\
\text { time emission, } \\
{[\mathrm{g} / \mathrm{sec}]}\end{array}$ & $\begin{array}{c}\text { summary } \\
\text { emissions } \\
\text { [tons / year] }\end{array}$ \\
\hline \multirow{6}{*}{$\begin{array}{l}\text { First Gravel } \\
\text { Processing Line }\end{array}$} & Receiving hopper & 0.013549 & 0.063840 \\
\hline & $\begin{array}{l}\text { Crushing-screening } \\
\text { line } 1\end{array}$ & 0.432638 & 4.360965 \\
\hline & Storage for dropout & 0.049192 & 0.509403 \\
\hline & $\begin{array}{l}\text { Storage for small } \\
\text { rubble }\end{array}$ & 0.040857 & 0.400705 \\
\hline & $\begin{array}{l}\text { Storage for large } \\
\text { rubble }\end{array}$ & 0.109789 & 1.290321 \\
\hline & Loading & 0.105856 & 0.114324 \\
\hline \multirow{6}{*}{$\begin{array}{l}\text { Second Gravel } \\
\text { Processing Line }\end{array}$} & Receiving hopper & 0.013549 & 0.032256 \\
\hline & $\begin{array}{l}\text { Crushing-screening } \\
\text { line } 2\end{array}$ & 0.532113 & 2.681847 \\
\hline & Storage for dropout & 0.045015 & 0.254954 \\
\hline & $\begin{array}{l}\text { Storage for small } \\
\text { rubble }\end{array}$ & 0.035377 & 0.200353 \\
\hline & $\begin{array}{l}\text { Storage for large } \\
\text { rubble }\end{array}$ & 0.088815 & 0.645161 \\
\hline & Loading & 0.112078 & 0.091140 \\
\hline \multirow{5}{*}{$\begin{array}{l}\text { Third Gravel } \\
\text { Processing Line }\end{array}$} & Receiving hopper & 0.020222 & 0.035280 \\
\hline & $\begin{array}{l}\text { Crushing-screening } \\
\text { line } 3\end{array}$ & 0.473161 & 1.703375 \\
\hline & Storage for dropout & 0.136568 & 0.707689 \\
\hline & $\begin{array}{l}\text { Storage for small } \\
\text { rubble }\end{array}$ & 0.121839 & 0.643382 \\
\hline & Loading & 0.104484 & 0.071467 \\
\hline \multirow[t]{2}{*}{$\begin{array}{l}\text { Storages for waste } \\
\text { products }\end{array}$} & $\begin{array}{l}\text { Storage for waste } \\
\text { products } 1-2\end{array}$ & 0.280863 & 2.691730 \\
\hline & $\begin{array}{l}\text { Storage for waste } \\
\text { products } 3\end{array}$ & 0.228426 & 0.780628 \\
\hline $\begin{array}{l}\text { Areas for land } \\
\text { restoration }\end{array}$ & $\begin{array}{l}\text { Road-building } \\
\text { machines }\end{array}$ & 0.055533 & 1.693440 \\
\hline $\begin{array}{l}\text { Areas for gravel } \\
\text { extraction }\end{array}$ & Excavator & 0.047686 & 0.052069 \\
\hline
\end{tabular}

A map of the concentration distribution in the area of the location of the enterprise has been constructed (Fig. 1), according to the results of calculations. The map contains the boundary of the areas of the enterprise, the boundary of the sanitary protection zone and calculated points. The calculated points show the concentration of inorganic dust in fractions of the MPC.

The maximum concentrations of inorganic dust at the calculated points on the boundary of the sanitary protection zone do not exceed the maximum permissible concentration $(0.24$ $\div 0.68$ MPC). Criterion (1) is met, i.e. this company does not make a negative impact on the atmosphere. 


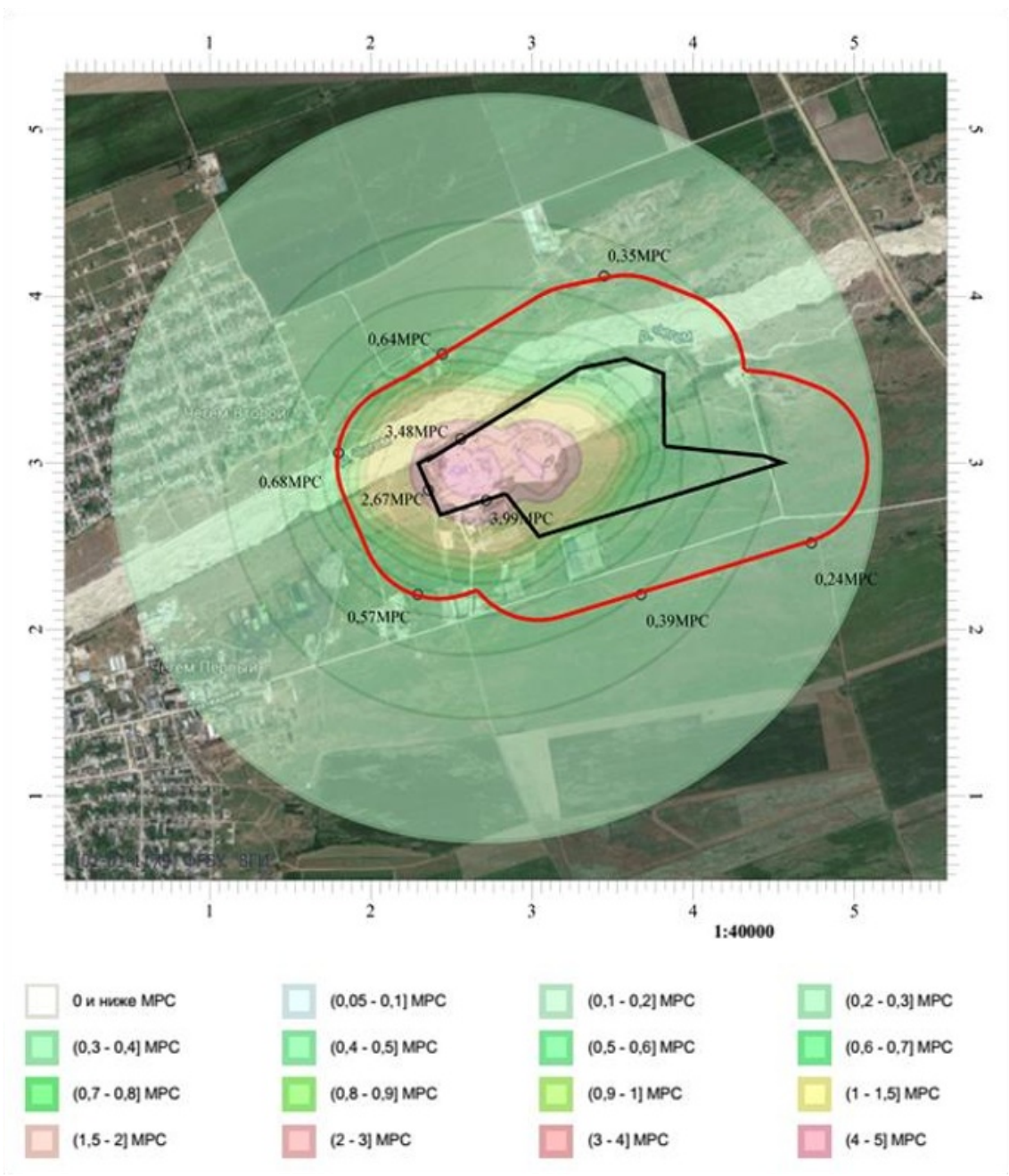

Fig.1. Inorganic dust dispersion map in the area of the enterprise location: the red polygon is the boundary of the sanitary protection zone, the black polygon is the boundary of the enterprise

At the same time, the maximum concentrations of inorganic dust at points at the enterprise's border exceed the value of the maximum permissible concentration $(2.67 \div 3.99$ MPC). What is requires carry out production environmental control.

The maximum concentration of dust of inorganic formed at a wind speed of $0.5 \mathrm{~m} / \mathrm{sec}$ and the direction of 95 degrees.

Sources contributing the most to the level of air pollution are shown in Table 2. The greatest contribution to air pollution is made by crushing - screening lines.

They account for about $50 \%$ of all emissions. At the same time, the main sources of dust emission are crushers and screens, the maximum one-time emission of which is $0.67 \mathrm{~g} / \mathrm{sec}$. 
Table 2. Sources contributing most to the level of air pollution

\begin{tabular}{|c|c|c|c|c|}
\hline \multirow{2}{*}{$\begin{array}{l}\text { The } \\
\text { calculated } \\
\text { points on } \\
\text { the SPZ }\end{array}$} & \multirow{2}{*}{$\begin{array}{l}\text { Maximum ground } \\
\text { level } \\
\text { concentration on } \\
\text { the boundary of } \\
\text { the SPZ [sh } \\
\text {. MPC] }\end{array}$} & \multicolumn{3}{|c|}{$\begin{array}{l}\text { Sources contributing most to the level of air } \\
\text { pollution, } \%\end{array}$} \\
\hline & & $\begin{array}{c}\text { crushing- } \\
\text { screening line } \\
1\end{array}$ & $\begin{array}{c}\text { crushing- } \\
\text { screening line } \\
2\end{array}$ & $\begin{array}{c}\text { crushing- } \\
\text { screening line } 3\end{array}$ \\
\hline 1 & 0.24 & 15 & 18 & 15 \\
\hline 2 & 0.35 & 17 & 19 & 16 \\
\hline 3 & 0.64 & 19 & 25 & 9 \\
\hline 4 & 0.68 & 19 & 27 & 8 \\
\hline 5 & 0.57 & 19 & 25 & 9 \\
\hline 6 & 0.39 & 17 & 19 & 16 \\
\hline
\end{tabular}

Thus, the operation of an enterprise for the extraction and processing of gravel does not lead to an excess of hygienic standards for the quality of atmospheric air on the boundary of SPZ. Therefore, existing emissions can be taken as regulatory.

\section{Conclusion}

It is shown that the emissions of inorganic dust on the area of the enterprise exceed the values of the maximum permissible concentration and become lower than the MPC only outside the sanitary protection zone. In general, summary emissions are a significant quantity, which is desirable to reduce. Reduction of emissions can be achieved through the use of dust cleaning devices (electric, hydrospray, aspiration). Ecological situation - is the quality of the environment, the state of which largely determines the level of public health. In recent years, there has been a clear tendency to increase the influence of the unfavorable environmental situation on public health and the demographic situation in Russia. Radically reduce the environmental burden on the relevant areas of mining operations could be government incentives for the extraction of nonmetallic building materials by underground mining.

\section{References}

1. L. T. Sozaeva, Materials Science Forum, 931, 1047-1051 (2018).

2. L.T. Sozaeva, I. Kh. Shungarov, Advances in Engineering Research, 182, 285-289 (2019).

3. Methodological gratuity on calculating emissions from unorganized sources in the building materials industry, NIPIOTSTROM, Novorossiysk, (2000).

4. Methodological gratuity on calculate, norming and controlling emissions of pollutants in the atmospheric air, Research Institute Atmosphere, St. Petersburg, (2012).

5. About approval of methods of measuring dispersion of emission of pollutants in the atmospheric air, Order of the Ministry of natural resources and ecology of the Russian Federation from 6 June 2017, Ministry of Justice of the RF, Moscow, (2017).

6. SanPiN. 2.2.1/2.1.1.1200-03, Hygienic standards 2.1.6.1338-03.

7. https://www.meteoblue.com 